\title{
THE SPANISH SCHOOL AS A FORERUNNER TO THE ENGLISH SCHOOL OF INTERNATIONAL RELATIONS ${ }^{1}$
}

\author{
Nicolás LEWKOWICZ \\ University of Nottingham
}

\begin{abstract}
RESUMEN: El propósito de este artículo es presentar a la tradición escolástica española del siglo XVI, con particular énfasis en la obra de Francisco de Vitoria, como precursora de la Escuela Inglesa de las Relaciones Internacionales. El artículo sitúa la discusión de los conceptos de 'guerra justa', la legitimidad de la conquista de las Indias y la subyugación de sus habitantes en el contexto histórico del sistema político internacional naciente. El artículo esboza también las circunstancias históricas que dieron lugar al advenimiento ideológico de la llamada Escuela de Salamanca o Escuela Española y compara los conceptos del derecho internacional y la 'sociedad internacional' explicados por la Escuela Española y la Escuela Inglesa.
\end{abstract}

PALABRAS CLAVE: derecho internacional, guerra justa, sociedad internacional, Escuela Española, Escuela Inglesa de Relaciones Internacionales.

ABSTRACT: The purpose of the paper is to expose the $16^{\text {th }}$ century Spanish scholastic tradition (and particularly the work of Francisco de Vitoria) as a forerunner to the English School of International Relations. The paper situates the discussion of the concepts of 'just war', the legitimacy of the conquest of the Indies and the subjugation of its inhabitants within the historical context of the nascent international political system. The paper also outlines the historical background of the Spanish School and draws comparisons between the concepts of international law and 'international society' as understood by the Spanish School and the English School of International Relations.

KEYWORDS: International law, Just war, International society, Spanish School, English School of International Relations.

\section{HISTORICAL BACKGROUND}

The dominant position of the Spanish Empire in the European political system, the upheaval brought about by the Reformation and the Iberian exploration and

1 An earlier draft of this paper was presented at the $6^{\text {th }}$ Pan-European International Relations Conference, Turin, Italy, September 12-15, 2007. I thank Peter Wilson (LSE), Yale Ferguson (Rutgers University), Richard Little (Bristol University) and Professor Barry Buzan (LSE) for their comments. 
conquest of the New World during the $15^{\text {th }}$ and $16^{\text {th }}$ century ${ }^{2}$ prompted the establishment of a new concept of international law and spawned a transition from a Middle Age system of rigid legal principles to one based on a system of states. These transformations were tackled via the debate on the legitimacy of the conquest at the Valladolid Council (1550-1551) ${ }^{3}$, in which the juxtaposing views of Juan Ginés de Sepúlveda and Bartolomé de las Casas took centre stage. The issues discussed included the right of conquest, the concept of just war and the conversion of the indigenous population in the New World into the Christian faith.

The debate was generated by the opposition to the New Law of the Indies (1542). Sepúlveda contributed to the debate with a tractate entitled Demócrates Alter, maintaining that the natives, as inferior human beings, had to be subjected to Spanish rule on the grounds that they were incapable of governing themselves. In addition to this, Spanish rule over the natives would prevent the practise of cannibalism, human sacrifices and idolatry as well as facilitate the evangelical role of the Church. Las Casas replied with his Apologia, using the example of Aztec architecture in an attempt to 'prove' that the natives were indeed rational human beings. It is worth mentioning that both positions justified the inalterable fact of the Spanish conquest. Although the debate on the legality of the conquest responded to the need to justify the moral basis for the Spanish rule over the Indies, it mainly focused on ensuring the political viability of the colonisation project.

The intense deliberations undertaken by the members of the Salamanca School consolidated a renewed notion of international law and just war as institutions of the nascent society of states. I will now turn my attention to the outcome of the debate on the institutions which would sustain the Spanish colonisation project and how these foreran English School thinking on international society.

\section{THE SPANISH SCHOOL AND THE CREATION OF AN INTERNATIONAL LAW FOR THE SOCIETY OF STATES}

The new realities of the international order gave rise to the idea of an 'international community'. This concept was first outlined by the Salamanca School, which included Francisco de Vitoria, Francisco Suárez, Domingo de Soto,

\footnotetext{
2 The legal instruments that Spain utilised in order to legitimise the conquest of the Indies were the Papal Bull issued by Pope Nicholas V in 1455 and the Treaty of Tordesillas, signed with Portugal at the end of the fifteenth century.

${ }^{3}$ From 1511 onwards, the legal rights of conquest by Spain were debated through the asambleas, culminating in the Laws of Burgos (1513) which set the legal framework for the Spanish Emperor to launch war against the natives who resisted their conversion into Christianity.
} 
Francisco Vázquez de Menchaca, Martín de Azpilicueta and Tomas de Mercado. These scholars analysed the law in an abstract manner, arguing that inter-state relations were to be governed by ethical norms and natural law principles, hence opposing the Machiavellian principle of raison d'etat. The Salamanca School defended what they perceived to be the natural rights of man, particularly those related to the body (right to life, to own property, etc) and to the soul (freedom of expression, to dignity, etc). The Salamanca School distinguished two legal domains: the civil and supranatural. In a clear break from the Middle Age legal tradition, this distinction entailed that the King or Emperor did not have any jurisdiction over the soul and the Pope none on the temporal. Furthermore the people were to devolve sovereignty to the Emperor according to the right circumstances ${ }^{4}$.

Suárez sustained that the nation was the unit of the international community inasmuch as the individual was for the natural society. Suárez distinguished a necessity in the association between states, based on the principles of natural law and custom. In Civil Power (De potestate civili) Vitoria proposed the idea of a community of peoples based on natural law, therefore departing from Machiavelli's view of the state as a morally-autonomous entity ${ }^{5}$ Vitoria's contribution to the development of the concept of international society revolved around the concept of the derecho de gentes (ius gentium), which included four basic postulates. First, that the natives be recognised as owners of their own land. Hence, their polities, although non-Christian, were to be conferred the same rights as the European states. Second, Vitoria opposed the Spanish Emperor's right to recognise himself as the owner of the world and, likewise, the papal right to assign territories to other princes or rulers. Third, the discovery of 'new' land does not give right of possession. Finally, Vitoria endorsed the view that the natives ought to give freedom to the Spaniards for the extension of the Christian religion, but any refusal on their part ought not to give rise to a right of conquest.

This approach entails a principle of recognition which foreruns the 'pluralist' idea of international society. Vitoria rejected Charles V claim for global supremacy observing that the political world was becoming one of separate princely states. $\mathrm{He}$

${ }^{4}$ In Defense of the Faith Against the Errors of the Anglican Sect/Defensio Fidei Catholicae adversus Anglicanae sectae errores (1613) Suárez states that 'The human race, though divided into different nations and status still has a certain unity...politically and morally. Each polity, republic or kingdom is a member of this universal society. This needs a love by which they are guided and rightly ordered in respect to communication and association'.

${ }^{5}$ See Machiavelli, N. (1985). The Prince, Chicago: University of Chicago Press. 
associated natural law with ius gentium and laid down the idea of a world composed of equal, separate sovereignties. This resembles the pluralist view of international society endorsed by Bull, in which international relations are constituted through rational fixed principles of interaction and coexistence (sovereignty, diplomacy and international law) without the precondition of a common identity or culture. It also approximates the view upheld by Jackson, who refers to the independence of states in order to endorse 'jurisdictional pluralism' as the constitutional basis of world politics, permitting states to compose their own 'domestic values and orchestrate them in their own way'.

The contribution made by the Spanish School in the field of international law anticipates the English School notion of a society of states made up of entities which are internally constituted by different political systems. Moreover, the Spanish School envisaged a society of states transcending racial boundaries. In addition to this, for the first time in modern times, the limits of Empire and Church were clearly demarcated. This would have a significant influence on the way the Spanish School would view the notion of just war and the nature of the international society.

\section{THE SPANISH SCHOOL AND THE NOTION OF JUST WAR AS AN INSTITUTION OF INTERNATIONAL SOCIETY}

Derived from this newly-constituted concept of international law is the concept of the just war. Vitoria thinks of war as a punitive action conditioned by three elements: competent authority, just cause and proportionality. Like Vitoria, Domingo de Soto (1495-1560), a confessor of Charles V, believed that idolatry was not a cause for Christians to declare war against the natives and that infidels could not be punished for being free from allegiance to Emperor or Pope.

Covarrubias rebutted the notion of a war of aggression but upheld the use of force in order to enforce civilisation. According to this criterion, war was only licit in defense of innocent people immolated in the service of civilisation and Catholicism. Covarrubias maintained that the state could intervene militarily in order to defend the subjects of any state, to liberate them from oppression and to protect Christians. Suárez gave as an example of a just cause for war, a potential conflagration against Henry VIII, as the English monarch had caused a break in the international order. Here we have an example that would provide states with a

\footnotetext{
${ }^{6}$ JACKSON, R. (1995). The Political Theory of International Society in Booth, K. and Smith S., International Relations Theory Today, Cambridge, Polity Press, pp. 178-9.
} 
guide for action in future system-shaping events as Suárez is in fact advocating the principle of war as a corrective element in international society.

Indeed, in clear similarity with the solidarist approach of the English School, intervention is endorsed by Vitoria 'in favour of those who are oppressed and suffer wrong'. Vitoria, stated however that intervention was tantamount to 'war', and that it should be exercised 'always... with an intent directed more to the welfare of the aborigines' than for imperial gain. Vitoria had the preservation of the international order at the core of his thinking on the causes for waging a just war

I should regard any war which is useful to one commonwealth or kingdom but of proven harm to the world or Christendom as, by that very token, unjust. Thus if Spain declares war on France for reasons which are otherwise just, and even if the war is useful to the kingdom of Spain if the waging of the war causes greater harm and loss to Christendom...then hostilities should be suspended ${ }^{7}$.

Vitoria's thinking foreruns the pluralist view of the English School when he states that 'difference of religion cannot be a cause of just war' and that neither 'enlargement of empire' nor the 'personal glory or convenience of the prince' can be just causes for waging war $^{8}$. Vitoria put further moral restraints on the use of force by stating that 'if the war seems patently unjust to the subject, he must not fight, even if he is ordered to do so by the prince'. He also stated that 'all those who are admitted or called of their own accord to attend the public or royal council are duty bound to examine the cause of just war' ${ }^{9}$.

As to the question of whether one may kill innocent people in a just war, Vitoria maintained that 'it is never lawful in itself intentionally to kill innocent persons'. He also added that 'it is occasionally lawful to kill the innocent not by mistake, but with full knowledge of what one is doing, if this is an accidental killing ${ }^{10}$. Vitoria argued for the plunder of 'goods and property which have been used...by the enemy'. At the same time, if the enemy refuses to restore the property they have unjustly seized, and the injured party is unable to recover his property in any other way 'he may seek redress in any way he chooses, from the innocent or the guilty' ${ }^{11}$.

\footnotetext{
${ }^{7}$ Vitoria, Francisco de, De Potestate Civili (On Civil Power) 1.13.

${ }^{8}$ Vitoria, Francisco de, De Iure Belli, 1.3.

${ }^{9}$ Vitoria, Francisco de, De Iure Belli 2.2.

${ }^{10}$ Vitoria, Francisco de, De Iure Belli 3.1.

${ }^{11}$ Vitoria, Francisco de, De Iure Belli 3.2.
} 
Vitoria stated that 'one may lawfully enslave the innocent under just the same conditions as one may plunder them', and that 'if the hostages would otherwise be combatants...[and] they have already borne arms against us, they may be executed'. ${ }^{12}$ Victoria also indicated that 'after victory has been gained and the matter is beyond danger' it was lawful to kill all the enemy combatants' but that 'it is not always lawful to execute all the combatants for the sole purpose of avenging injury'13. Vitoria prescribed that 'all booty taken in a just war up to a value sufficient to recompense the property unjustly seized by the enemy, and also including reparation of the costs of the war, [should] become the property of the captors' and that 'soldiers may not plunder or burn without the authority of their prince or commander' ${ }^{14}$.

With its emphasis on moral and legal restraints on the use of force, Spanish School thinking anticipates Grotius' Rationalist observations on conflict ${ }^{15}$ and Bull's concept of war as a method of enforcing the law and preserve international society ${ }^{16}$. It is only when war is seen as an instrument to preserve the society of states that a modern international political system can fully emerge. Referred to by Bull as 'organised violence carried on by political units against each other' ${ }^{17}$, the function of war has been defined as one of the means by which states' objectives were attained. The attainment of these objectives presupposes a rational approach for ascertaining the just causes for war-waging, which are analysed at length by Vitoria. It is the Spanish School's merit to link the notion of just war to the preservation of the society of states and to read the historical transformations of the sixteenth century not as a heretic anomaly but as a clear break from the medieval

${ }^{12}$ Vitoria, Francisco de, De Iure Belli 3.3-4.

${ }^{13}$ Vitoria, Francisco de, De Iure Belli 3.5.

${ }^{14}$ Vitoria, Francisco de, De Iure Belli 3.6-7.

15 In De Jure Belli ac Pacis Grotius proposes that war should be launched 'where there is a violation of rights, there is a judicial solution; where there is no judicial situation there is war'.. See YASUAKI, O. (ed) (1993), A Normative Approach to War-Peace, War, and Justice in Hugo Grotius, Oxford, Clarendon Press, pp. 351-2.

${ }^{16}$ Bull H., The Anarchical Society, p. 188-9. Bull also states that 'international society has seen war at least from the beginning of the $18^{\text {th }}$ century as a means to preserve the balance of power and to bring about just change'. See Bull, H. (1973). War and International Order in James, A. (ed), The Bases of International Order-Essays in Honour of C A W Manning, London and New York., Oxford University Press, pp. 120-1.

${ }^{17}$ Bull, H. (1973). War and International Order in James, A. (ed), The Bases of International Order-Essays in Honour of C. A. W. Manning, London and New York, Oxford University Press, p. 116. 
tradition into a new concept of legally-bound interaction between diverselyconstituted polities.

\section{THE SPANISH SCHOOL AND THE CONCEPT OF INTERNATIONAL SOCIETY}

With his view of the common good as supreme over the good of each state, Vitoria resuscitated the Roman concept of universal law of humanity. Vitoria adds another dimension to the thinking on inter-state relations with his theory of the ius inter gentes for the conduct of relations between people/s. In Vitoria's theory, gentes included individuals and nations. This has a resemblance to Bull's dictum of individuals as the ultimate reality of the international political system ${ }^{18}$. Another addition of Vitoria is his ius communicationis which results from the natural sociability of human beings, or the natural law of communication between gentes, which cannot be broken without just cause and can be forcefully enforced. This echoes Bull's view of international society, which he perceived as a group of states bound by rules in their relations with one another and sharing common institutions ${ }^{19}$. According to Bull, the goals of international society are the preservation of the system and the society of states itself, the maintenance of external sovereignty (subordinate to the preservation of the society of states itself, by way of balance of power) and the goal of peace, to be breached only on special occasions $^{20}$.

Another forerunning feature of Vitoria's thesis is his emphasis on the respect for inter-cultural co-existence, approximating his view to that of the pluralist notion of international society. Vitoria argued that independent states are not isolated but united by a common origin, similar needs and limitations, which facilitates their harmonious engagement. These independent states therefore constitute themselves into an international community which is bound to live interdependently.

In De Indis, Vitoria questioned the titles of conquest that the Spanish Empire arrogated itself in order to legitimise the Spanish conquest $\mathrm{t}^{21}$. Vitoria upheld the

\footnotetext{
${ }^{18}$ See Bull, H. (1995). The Anarchical Society, Basingstoke, Macmillan.

${ }^{19}$ Bull, H., The Anarchical Society, p. 13.

${ }^{20}$ Bull, H., The Anarchical Society, p. 17.

${ }^{21}$ The Papal Bull (Romanus Pontifex) issued by Nicholas V to King Afonso V of Portugal on January 8, 1455, extended to the Catholic nations of Europe the right to establish a dominion over the conquered lands. In 1493 Pope Alexander VI issued another Papal Bull (Inter Caetera) stating that one Christian nation did not have the right to establish dominion over lands previously dominated by another Christian nation.
} 
right of the natives to own their land, to self-government and to elect its leaders. In line with this thinking, Vitoria maintained that the legitimate instruments for the Spanish conquest were the ius communicationis, the defense of the faith once the natives accepted it and the tutelage of the natives. Within this right of tutelage, Vitoria includes the right of humanitarian intervention in case of a violation of natural law (as in the case of the performance of human sacrifices).

Vitoria upheld the principle that every nation can constitute itself into an independent respublica and that every 'republic' is integrated in world politics for being part of mankind. For the first in modern times, a political theory of intercultural dimension is formulated. Vitoria broke with the Medieval Christian concept of a universal monarchy, as epitomised in the ecumenical aspirations of the Holy Roman Empire. In Vitoria's thinking, this community of nations is made up by different religions and cultures and bound by the ius gentium. Vitoria conjectured that even if the members of an international community were not willing to relinquish their sovereignty to a universal political entity; the binding of every member state of the international community under the umbrella of an ecumenical authority of sorts was nonetheless achievable. This view is centuries later taken by Bull, who maintained that states are socialised by the structure of the international system where elementary rules of co-existence are formulated ${ }^{22}$.

According to Brown Scott, Vitoria disqualified the assumption that the principalities of the Indies ought to be excluded from this international community. In accordance with his theory of international law, they were members possessing the same rights and the same duties as the Christian States of Europe ${ }^{23}$.

This is manifested on the question of the legitimacy of non-Christian sovereigns and magistrates. Vitoria remarks that

there can be no doubt at all that the heathen have legitimate rulers and masters... Joseph and Daniel served as ministers and governors to pagan rulers. So neither Christian sovereigns nor the church may deprive non-Christians of their kingship or power on the grounds of their unbelief, unless they have committed some other injustice ${ }^{24}$.

\footnotetext{
${ }^{22}$ Bull H., The Anarchical Society, p. 16-9.

${ }^{23}$ Brown SCOTt, J., The Spanish Origin of International Law, p. 281-2.

${ }^{24}$ Vitoria, Francisco de, De Potestate Civili (On Civil Power) 1.9.
} 
In Vitoria's thinking, the natives, as members of the international community, had legitimate sovereign rights

barbarians are not impeded from being true masters, publicly and privately, either by mortal sin in general or by the particular sin of unbelief. Nor can Christians use either of these arguments to support their title to dispossess the barbarians of their goods and lands... ${ }^{25}$.

Vitoria included within the list of unjust titles by which the natives could become subjects of the Spanish Emperor the claim that possession was by right of discovery, refusal to accept Christianity, voluntary choice of the barbarians (under certain circumstances) or by special gift from God. ${ }^{26}$ Among the just titles, he enumerated 'natural partnership and communication', 'the spreading of the Christian religion', 'the protection of converts', 'papal constitution of a Christian prince', 'in defense of the innocent against tyranny', 'true and voluntary election', 'for the sake of allies and friends' and 'mental incapacity of the barbarians, ${ }^{27}$.

Vitoria argued that it is lawful 'to impose tribute on a defeated enemy', although not always lawful 'to depose the enemy's princes and set up new ones ${ }^{28}$. He concluded that princes 'should strive above all to avoid all provocations and causes of war'. War should be pursued 'for the pursuit of justice for which he fights and the defense of his homeland' and victory should be 'used with moderation and Christian humility ${ }^{29}$.

On the question of the conversion of unbelievers, Vitoria derived from Aquinas that more harm than good follows from forcible conversion. He argued that forcible conversion would cause great provocation and unrest among the heathens and that forcible conversion would generate immense hate in them and give rise to pretence and hypocrisy ${ }^{30}$.

In the same vein, Soto wrote that the function of the legislator is to benefit its citizens and to imbue good customs in a just and harmonious society. An overextended empire was an impediment to that objective and could not be

\footnotetext{
${ }^{25}$ Vitoria, Francisco de, De Indis 1.3.

${ }^{26}$ Vitoria, Francisco de, De Indis 2.2-2.7.

${ }^{27}$ Vitoria, Francisco de, De Indis 3.1-3.8.

${ }^{28}$ Vitoria, Francisco de, De Iure Belli 3.9.

${ }^{29}$ Vitoria, Francisco de, De Iure Belli, Conc.

${ }^{30}$ Vitoria, Francisco de, On the Evangelisation of unbelievers s. 1, Relectiones Theologicae.
} 
legitimised. For Soto, the notion of 'imperium', as created by Rome and sanctioned by Christ, was reduced to a mere res publica, which had a limited extension. Menchaca upheld the freedom of the seas as a primary principle of the ius gentium and as such, immutable, eternal, and not subject to the fact that a particular country like Spain could exercise dominion over them. Menchaca opined that because of the multifarious nature of mankind, extending the authority of a particular society all over the world would be 'inadequate, pernicious and dangerous' and against nature. At the same time, Covarrubias believed that the natural solidarity among peoples induced interdependence which could make some states intervene in help of others. However, like Soto, Covarrubias underscored Aristotle's dicta that if it was difficult to govern a great number of cities, it would be impossible to govern the whole world, concluding that 'by natural law and by own nature, it was not conceded to an Emperor the jurisdiction of the whole world ${ }^{31}$.

The Spanish School looked beyond Spain's significant political, economic and military leverage in order to rebut the concept of Empire and endorse the notion of a society of states. By subscribing to the notion of an international community capable of respecting ideological and cultural differences, the Spanish School anticipated Bull's notion of an 'anarchical society' and the pluralist notion of the society of states endorsed by Jackson.

The Spanish School, and particularly Vitoria, was nonetheless aware of the possibility of a solidarist stream in international society thinking via the possibility of intervention. English School solidarists like Vincent stress substantial values and a common tradition as the normative foundation of international society based on the principle of solidarity and ethical universalism ${ }^{32}$. Vincent argues that if states systematically and massively violated human rights 'then there might fall to the international community a duty of humanitarian intervention, ${ }^{33}$. Vitoria defends intervention in order to preserve international society. Vitoria, like the rest of the members of the Spanish School, believed in the civilisational role of Spain and the Church and the universal scope of international law. Alvarado argues that 'the discovery of hitherto unknown indigenous peoples on an unknown continent, and the necessity to determine Spain's moral and legal relationship to those peoples,

${ }^{31}$ See MenchaCA, F, Controversarium Illustrium.

32 VInCENT, R. J. (1986). Human Rights and International Relations, Cambridge. Published in association with the Royal Institute of International Affairs by Cambridge University Press, p. 126. See also VInCENT, R. J. (1974). Nonintervention and international order, Princeton, N.J: Princeton University Press.

${ }^{33}$ VINCENT, R. J., Human Rights and International Relations, p. 127. 
forced Vitoria and his followers to apply the jus gentium beyond the framework of Europe and East Asia ${ }^{34}$.

The belief that interstate interaction can exist within clearly defined legal and ethical parameters aiming at protecting the ideological and cultural diversity of the system anticipates English School thinking. The intellectual efforts of the Spanish School contributed to enhance the notion of the role of international law and diplomatic intercourse as institutions of the international political system. The concept of primary institutions, at the heart of English School thinking, would evolve in the twentieth century, particularly with the expansion of international society. Wight enumerates the primary institutions of the international society of the first half of the twentieth century, as 'diplomacy, alliances, guarantees, war and neutrality ${ }^{35}$. Bull updated and expanded the concept with his set of five institutions of international society consisting of diplomacy, international law, the balance of power, war and the role of great powers ${ }^{36}$. The Spanish School earmarked international law, the concept of just war and of regular interaction between states as primary institutions of the nascent system of states. These institutions would facilitate the colonisation project in the Indies. However, the Spanish School analysed the legitimacy of the conquest in the context of a renewed concept of ethics and international law, foreseeing the establishment of an international community which transcended cultural and racial differences and respected the primacy of the state over Empire and Church.

\section{SELECT BIBLIOGRAPHY}

AtKInson, W. (1961). A History of Spain and Portugal, Harmondsworth: Middx, Penguin Books.

AlvaradO, R. (1994). "Fountainhead of Liberalism", Contra Mundum, 10, Winter. Federalism.

BROWn Scott, J. (1934). The Spanish Origin of International Law, The Clarendon Press: London.

Booth, K. and SMITH S. (1995). International Relations Theory Today, Polity Press: Cambridge.

Bull, H. (1995): The Anarchical Society, Basingstoke: Macmillan.

CANO, Melchor. (1962) Tratados espirituales. Estudio preliminar y edición preparada por Vincente Beltran de Heredia, Madrid: Editorial Católica.

\footnotetext{
${ }^{34}$ Alvarado, R.. (1994). "Fountainhead of Liberalism", Contra Mundum, 10, Winter. Federalism.

${ }^{35}$ Wight, M. Power Politics, pp. 111-2.

${ }^{36}$ Bull, H. The Anarchical Society, pp. 101-229.
} 
Hamilton, B. (1963). Political thought in sixteenth-century Spain: a study of the political ideas of Vitoria, De Soto, Suârez, and Molina, London and New York: Oxford University Press.

JAMES, A. (ed.). (1973). The Bases of International Order-Essays in Honour of $C A W$ Manning, London and New York: Oxford University Press.

Kamen, H. (2002). Spain's Road to Empire-The Making of A World Power 1492-1763, London: Penguin Books.

Machiavelli, N. (1985). The Prince, Chicago : University of Chicago Press.

MENCHACA, Fernando Vázquez de, ControversiarumIllustriumhttp://www.seminariodefilosofiadelderecho.com/BIBLIOTECA/V.htm

Pagden, A. (1990). Spanish Imperialism and Political Imagination. Studies in European and Spanish-American Social and Political Theory, 1513-1830, New Haven and London: Yale University Press.

PAgDeN, A. (ed.) (1987). The Languages of Political Theory in Early-Modern Europe, Cambridge, Cambridge University Press.

Soto, Domingo De. De Justitia et Jure (1553). Ad Sanctum Concilium Tridentinum de natura et gratia libri tres http://es.wikipedia.org/wiki/Escuela_de_Salamanca.

Soto, Domingo de (1995): "Notas sobre el concepto de rapiña según Domingo de Soto", Anuario Mexicano de Historia del Derecho, No. 7, pp. 51-72.

SUAREZ, Francisco. (1995). Selections from three works of Francisco Suárez, S. J. Vol. 1, Buffalo, N.Y: Hein.

VINCENT, R. J. (1986). Human Rights and International Relations, Cambridge: Published in association with The Royal Institute of International Affairs by Cambridge University Press.

VINCENT, R. J. (1974). Nonintervention and international Order, Princeton, N.J: Princeton University Press.

VitORIA, Francisco de (1557) Relectiones Theologicae, Lugduni.

VITORIA, Francisco DE (1917). De Indis et de iure belli relectiones, being parts of Relectiones theologocae XII, edited by Ernest Nys, Washington: Carnegie Institution of Washington.

VITORIA, Francisco de (1991). Political writings, edited by Anthony Pagden and Jeremy Lawrance, Cambridge: Cambridge University Press.

WigHT, M. (1991). International Theory, London: Leicester University Press, a division of Pinter Publishers.

Wight, M. (1995). Power Politics, New York: Leicester University Press. 